\title{
Are ecophysiological responses influenced by crown position in cork-oak?
}

\author{
G Oliveira, C Werner, O Correia
}

\author{
Secção de Ecologia e Sistemática dos Vegetais, Dep de Biologia Vegetal, \\ Faculdade de Ciências de Lisboa, Campo Grande, C2, 4, 1700 Lisbon, Portugal
}

(Received 31 October 1994; accepted 18 July 1995)

\begin{abstract}
Summary - Montados and dehesas of Quercus ilex and Quercus suber occupy large areas in the Iberian Peninsula and are characterized by a low-density tree cover. The variability of responses within tree canopies in such open stands has been little studied. We investigated the variation of stomatal conductance within the crown of a cork-oak ( $Q$ suber $L$ ), by studying its diurnal and seasonal courses at two different heights and four directions within the canopy. Height did not strongly affect leaf response, as a consequence of the crown structure. Differences were found in microclimatic conditions and maximum stomatal conductance among directions. However, overall daily stomatal conductance was similar among different crown sections, suggesting that leaves develop different mechanisms to accomodate the microclimatic constraints which affect the particular position they occupy in the crown of cork-oak.
\end{abstract}

cork-oak / isolated tree / microclimate / stomatal conductance / within-crown variability

Résumé - Les réponses écophysiologiques sont-elles influencées par la position des feuilles dans la couronne du chêne-liège ? Les montados et dehesas de Quercus ilex et Quercus suber constituent une partie importante du couvert végétal de la péninsule lbérique et se caractérisent par une basse densité d'arbres. La variabilité de réponses au sein des canopées de ces arbres a été peu étudiée jusqu'à présent. L'évolution journalière et saisonnière de la conductance stomatique à différentes hauteurs et expositions a été étudiée au sein de la canopée d'un chêne-liège ( $Q$ suber $L$ ). La hauteur n'a pas influencé la réponse des feuilles. En revanche, on a trouvé des différences entre les orientations étudiées du point de vue des conditions microclimatiques et des conductances maximales. Cependant la conductance stomatique journalière était similaire entre les sections considérées, ce qui suggère que les feuilles développent des mécanismes différents pour faire face aux contraintes microclimatiques selon la position spécifique qu'elles occupent dans la canopée.

arbre isolé / chêne-liège / conductance stomatique / microclimat / variabilité dans la canopée 


\section{INTRODUCTION}

A tree crown may be seen as a large and heterogeneous population of branches and leaves, unequally subjected to environmental factors. It is thus questionable if studies on a few leaves or a branch will be adequate to represent the whole canopy. This is especially important in the field, where the application of ecophysiological measurements to large trees presents obvious methodological and financial problems.

Most studies on the gas exchange and water relations of Mediterranean tree species are restricted to young and small individuals (eg, Tenhunen et al, 1984; Rhizopoulou and Mitrakos, 1990; Acherar et al, 1992), or to a limited area of the mature tree crown (eg, Lo Gullo and Salleo, 1988; Oliveira et al, 1992), often the one exposed to the highest radiation levels. Although this sort of sampling may be useful for many purposes, and the only one possible in most cases, it is of little use in canopy models in which variation within the canopy is important (Dolman and van den Burg, 1988; Hollinger, 1989). Unfortunately only a few reports are available concerning withincanopy variability in tree species. Height in the canopy influences stomatal response (Dolman and van den Burg, 1988; Sala, 1992) and photosynthetic capacity (Hollinger, 1989), apparently due to the microclimate gradient developed from upper to lower canopy levels in closed forests.

Quercus suber $L$ is a main component of the typical montados and dehesas in the Iberian Peninsula and one of the most important forest species occurring in Portugal. The most striking feature of these oak stands is their savanna-like structure. Tree density is low (generally $<100 . \mathrm{ha}^{-1}$ ) and there is no strong competition for light. Trees are seldom higher than $10 \mathrm{~m}$, and develop large and wide crowns. Probably as a consequence of their growth and branching patterns (Oliveira et al, 1994), cork-oaks pre- sent rather diffuse crowns, and typical 'shade-leaves' (not directly sunlit) are thus rare.

Considering these characteristics, one might ask if within-crown variability exists in such trees and, in case it does, what are the sources of that variation. To address such questions, we studied the effects of different positions within the crown on the ecophysiology of a typical mature cork-oak in southwest Portugal.

\section{MATERIALS AND METHODS}

The study took place at the Herdade do Pinheiro, Portugal $\left(38^{\circ} 28^{\prime} \mathrm{N}, 8^{\circ} 42^{\prime} \mathrm{W}\right.$, altitude $\left.27 \mathrm{~m}\right)$. The stand is dominated by $Q$ suber $L$ and explored for pasture and cork production. The study years (1992 and 1993) were drier than usual, with an annual rainfall of ca $370 \mathrm{~mm}$. Data were collected monthly, from March to September.

The studies were performed on a single corkoak, representative of the stand and sufficiently isolated to prevent significant shading from neighbouring trees. The selected tree, with a stem circumference of $0.60 \mathrm{~m}$ (at $1.30 \mathrm{~m}$ ), was $10 \mathrm{~m}$ high and its crown diameter averaged $13 \mathrm{~m}$. Catwalks and towers were built around the tree in order to give access to branches in four directions (north, east, south and west) and two heights of the canopy: middle, at $5.5 \mathrm{~m}(\mathrm{M})$ and low, at $3 \mathrm{~m}(\mathrm{~L})$.

Diurnal courses of stomatal conductance $\left(g_{\mathrm{S}}\right)$, photosynthetic photon flux density incident on the leaf $\left(\mathrm{PPFD}_{i}\right.$ ), air temperature (Tair), and air-toleaf water vapour pressure difference (VPD) were determined with a steady-state porometer ( $\mathrm{LI}$ 1600, Li-Cor Lincoln, NE, USA). Readings were taken from three fully expanded leaves from different branches in each height and direction (section), at the periphery of the crown. The same leaves were measured throughout the year, whenever possible. Simultaneous determinations of water potential on neighbouring terminal shoots were made with a pressure chamber.

Differences among heights and directions were tested for the measured parameters, at each date, with two-factor analyses of variance.

Most results and discussions hereafter will only refer to north and south directions, which 
appeared to represent the canopy response extremes for the studied parameters.

\section{RESULTS AND DISCUSSION}

Although rainfall had been scarce in the previous autumn and winter months, water availability to the tree was high during the study period, as indicated by the predawn water potential values $(-0.2 /-0.5 \mathrm{MPa}$, fig $1 \mathrm{~A})$. No relevant differences in minimum daily water potential values were found, neither between $M$ and $L$ levels (not shown), nor between north and south sections (fig 1A).

The $P P F D_{i}$ was significantly affected by direction, but generally not by height in the crown (table I; fig 1B). However, some sig- nificant interactions between direction and height are suggested by the results. Tair and VPD were rather homogeneous within the crown and only showed a few differences among directions (table I).

Stomatal conductance was also more significantly affected by direction than by height within the canopy, during spring (table I). New leaves emerged in May, and their different development stage within the crown probably contributed to the significant differences among directions observed in this month. As the dry season progressed, $g_{\mathrm{s}}$ decreased, and no differences were found among directions for the studied parameters (fig $1 \mathrm{~B}$ and $\mathrm{C}$; table I). These results are different from those found for $Q$ robur (Dolman and van den Burg, 1988), where the stomatal response varied with the height

Table I. Comparison of the daily data obtained from leaves in two different heights $(\mathrm{H})$ and four directions (D).

\begin{tabular}{|c|c|c|c|c|c|c|c|c|c|c|}
\hline \multirow{2}{*}{\multicolumn{2}{|c|}{$\begin{array}{l}\text { Parameter } \\
\text { Factor }\end{array}$}} & \multicolumn{5}{|c|}{1992} & \multicolumn{3}{|c|}{1993} & \multirow[b]{2}{*}{$\begin{array}{r}\text { Septembe } \\
(n=24)\end{array}$} \\
\hline & & $\begin{array}{c}\text { April } \\
(n=15)\end{array}$ & $\begin{array}{c}\text { May } \\
(n=15)\end{array}$ & $\begin{array}{c}\text { June } \\
(n=24)\end{array}$ & $\begin{array}{l}\text { March } \\
(n=12)\end{array}$ & $\begin{array}{c}\text { April } \\
(n=27)\end{array}$ & $\begin{array}{c}\text { May } \\
(n=30)\end{array}$ & $\begin{array}{c}\text { June } \\
(n=30)\end{array}$ & $\begin{array}{c}\text { July } \\
(n=18)\end{array}$ & \\
\hline \multirow[t]{3}{*}{$g_{\mathrm{s}}$} & $D$ & * & * & ns & ** & * & $* *$ & ns & ns & ns \\
\hline & $\mathrm{H}$ & ns & ns & ns & * & ns & - & ns & ns & - \\
\hline & $\mathrm{D} \times \mathrm{H}$ & ns & ns & $\star$ & ns & ns & - & ns & ns & - \\
\hline \multirow[t]{3}{*}{ PPFD $_{i}$} & $D$ & 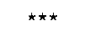 & ns & * & $\star \star \star *$ & $* * *$ & $\star \star \star *$ & ns & ns & $\star \star \star \star$ \\
\hline & $\mathrm{H}$ & ns & $\mathrm{ns}$ & $\mathrm{ns}$ & ns & ns & - & $\star$ & ns & - \\
\hline & $\mathrm{D} \times \mathrm{H}$ & ** & ns & $\star \star \star$ & ns & $* *$ & - & * & ns & - \\
\hline \multirow[t]{3}{*}{ VPD } & $D$ & ns & ns & $\star \star$ & ns & ns & $\star$ & ns & ns & ns \\
\hline & $\mathrm{H}$ & ns & ns & ns & ns & ns & - & $\mathrm{ns}$ & $\mathrm{ns}$ & - \\
\hline & $\mathrm{D} \times \mathrm{H}$ & ns & ns & ns & $\mathrm{ns}$ & ns & - & ns & $\mathrm{ns}$ & - \\
\hline \multirow[t]{3}{*}{ Tair } & $D$ & ns & $\mathrm{ns}$ & $\star$ & ns & ns & $\star *$ & ns & ns & * \\
\hline & $\mathrm{H}$ & ns & ns & ns & ns & ns & - & $\mathrm{ns}$ & ns & - \\
\hline & $\mathrm{D} \times \mathrm{H}$ & ns & $\mathrm{ns}$ & ns & $\mathrm{ns}$ & ns & - & $\mathrm{ns}$ & $\mathrm{ns}$ & - \\
\hline
\end{tabular}

Results from a two-factor ANOVA for each month. The number of daily measurements on single leaves $(n)$ is indicated. Data from 1993 refer only to north and south directions. ${ }^{\star \star *} P<0.001 ;{ }^{* *} P<0.01$; ${ }^{*} P<0.05$; ns: not significant; not determined. 
in the crown, but more similar to the ones reported for an isolated $Q$ alba tree (Aubuchon et al, 1978).

Maximum annual stomatal conductance varied among the different parts of the crown, decreasing in the sequence east -

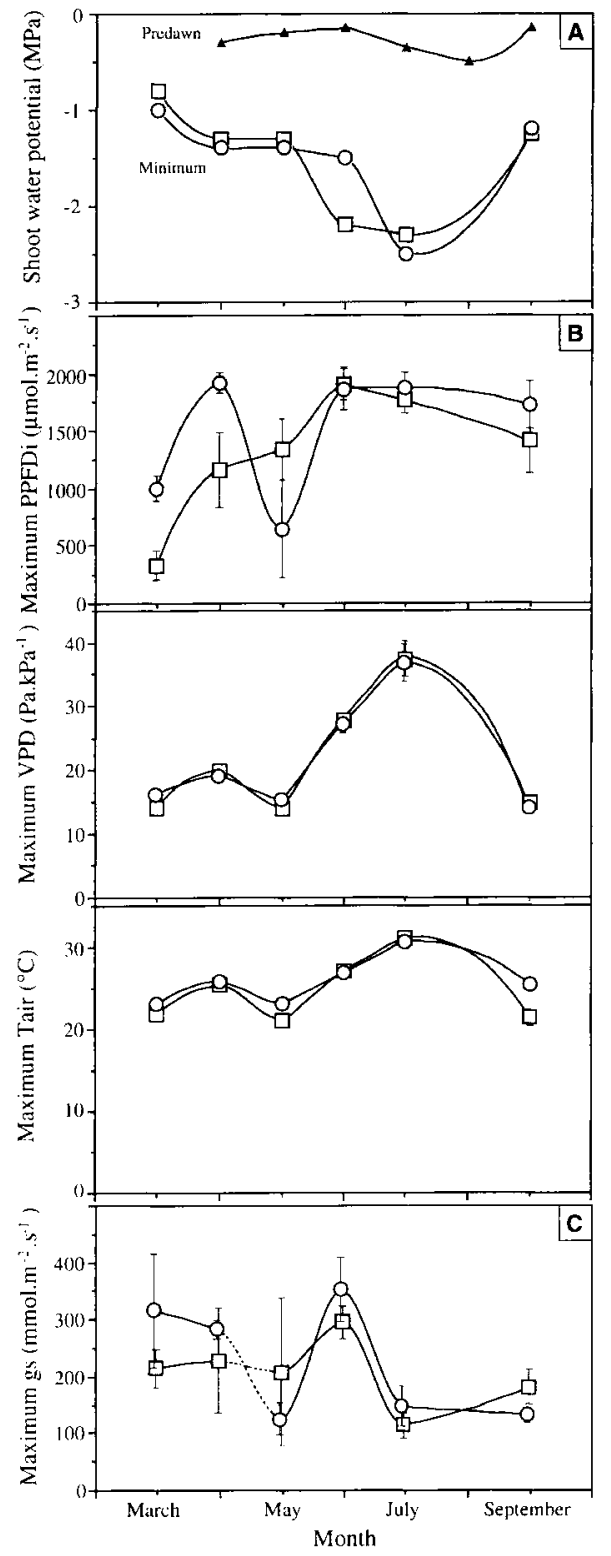

south - west - north (table II). They were recorded during spring, and generally in the morning, when VPD and Tair were below $21 \mathrm{~Pa} . \mathrm{kPa}^{-1}$ and $28^{\circ} \mathrm{C}$, respectively. Light $\left(P P F D_{i}\right.$ ) did not seem to play a major role in the maximum $g_{\mathrm{s}}$ measured in the field.

What prevents all leaves from attaining, and maintaining for longer periods, these high stomatal conductances? Light, the environmental factor which was different over the canopy, was apparently not the main restriction, since high conductances were measured under relatively low levels of PPFD $_{i}\left(<700 \mu \mathrm{E} \cdot \mathrm{m}^{-2} \cdot \mathrm{s}^{-1}\right.$, table II). Moreover, higher light intensities occurred throughout the day, without an increase in stomatal conductance. This was probably due to the increase in Tair and VPD which apparently became more limiting to $g_{\mathrm{S}}$ than $\mathrm{PPFD}_{i}$ after the first morning hours. In fact, the compromise VPD/Tair/PPFD differed among crown sections as the sun angle changed throughout the day and the year. It could thus be expected that east and south exposed leaves would be "favoured" because early in the day, when their water potential is high, the evaporative demand is low, and they receive enough light for photosynthesis.

But do leaves contribute differently to overall canopy productivity according to their position in the crown? Previous observations showed that south and west produced more branches and leaves (although smaller) than the other sections of the crown

Fig 1. Monthly progression of the studied parameters for north (squares) and south (circles) leaves in cork-oak. (A) Predawn and minimum shoot water potential. (B) Maximum photosynthetic photon flux density incident on the leaf $\left(P P F D_{i}\right)$, maximum vapour pressure difference (VPD) and maximum air temperature (Tair). (C) Maximum stomatal conductances $\left(g_{\mathrm{s}}\right)$; broken lines indicate the emergence of new leaves. In (B) and (C), each point is the average of three measurements and vertical lines represent standard deviations. Data from 1993. 
Table II. Maximum stomatal conductances $\left(g_{\text {smax }}\right)$ from cork-oak leaves in each crown section, and environmental conditions $\left(\right.$ PPFD $_{i}$, Tair and VPD) under which they were obtained. Averages are shown, referred to the three maximum $g_{\mathrm{s}}$ values recorded on single leaves.

\begin{tabular}{|c|c|c|c|c|c|c|}
\hline Direction & Height & $\frac{g_{\text {smax }}}{\left(m m o l ~ m^{-2} s^{-1}\right)}$ & $\begin{array}{c}P P F D_{i} \\
\left(\mu E m^{-2} s^{-1}\right)\end{array}$ & $\begin{array}{c}V P D \\
\left(P a k P a^{-1}\right)\end{array}$ & $\begin{array}{l}\text { Tair } \\
\left({ }^{\circ} \mathrm{C}\right)\end{array}$ & Time of day, month \\
\hline East & $\begin{array}{l}\text { Low } \\
\text { Middle }\end{array}$ & $\begin{array}{l}454 \\
380\end{array}$ & $\begin{array}{l}505 \\
616\end{array}$ & $\begin{array}{l}6.6 \\
9.7\end{array}$ & $\begin{array}{l}19.7 \\
21.6\end{array}$ & $\begin{array}{l}\text { Early morning, June } \\
\text { Early morning, June }\end{array}$ \\
\hline South & $\begin{array}{l}\text { Low } \\
\text { Middle }\end{array}$ & $\begin{array}{l}348 \\
406\end{array}$ & $\begin{array}{l}374 \\
787\end{array}$ & $\begin{array}{l}13.6 \\
21.3\end{array}$ & $\begin{array}{l}22.3 \\
27.7\end{array}$ & $\begin{array}{l}\text { Morning, June } \\
\text { Morning, May }\end{array}$ \\
\hline West & $\begin{array}{l}\text { Low } \\
\text { Middle }\end{array}$ & $\begin{array}{l}359 \\
385\end{array}$ & $\begin{array}{l}152 \\
117\end{array}$ & $\begin{array}{l}16.3 \\
15.8\end{array}$ & $\begin{array}{l}24.7 \\
24.5\end{array}$ & $\begin{array}{l}\text { Morning, May } \\
\text { Morning, May }\end{array}$ \\
\hline North & $\begin{array}{l}\text { Low } \\
\text { Middle }\end{array}$ & $\begin{array}{l}303 \\
314\end{array}$ & $\begin{array}{l}167 \\
316\end{array}$ & $\begin{array}{c}6.7 \\
15.4\end{array}$ & $\begin{array}{l}18.3 \\
23.4\end{array}$ & $\begin{array}{l}\text { Morning, April } \\
\text { Late morning, June }\end{array}$ \\
\hline
\end{tabular}

(Oliveira et al, 1993). However, despite the fact that south-facing leaves generally attained higher maximal conductances (table II; fig 1C), their daily stomatal contribution was not much different from that of north leaves (fig 2). This was because south leaves were exposed, not only to the most suitable environmental conditions (in the morning), but generally also to the strongest environmental demand (highest PPFD $i$ and VPD, in the early afternoon).

Rhizopoulou et al (1991) found that sun and shade leaves from Mediterranean species seem to have developed avoidance or tolerance mechanisms, respectively, to withstand their particular microclimatic conditions. Although the north leaves in our study are not characteristic shade leaves, our results appear to support that view. Different photosynthetic capacities within the canopy (Hollinger, 1989) might explain the high physiological performance of northexposed leaves under less favourable conditions than the rest of the crown.

In agreement with other studies (Rhizopoulou et al, 1991; Sala, 1992), withincrown variability was reduced during summer (table I), when environmental conditions became more critical (fig 1). It is worth noting that it was during the intensive growth period (spring) that differences among crown sections were apparent.

\section{CONCLUSION}

Microclimate varied more with direction than with height within the crown of the studied tree. Accordingly, height in the crown did not greatly affect stomatal conductance in this oak. It might be argued that the sampled crown heights were not sufficiently different, and that higher branches (eg, at 9 $\mathrm{m})$ would probably show different responses when compared to the lower ones. Even though this could be true, we believe that such differences would be small, due to the crown's size. Moreover, in these oaks, the largest proportion of leaves is located at the sampled levels and although the 'low' branches get occasionally shaded during the day by those above them, the 'middle' branches do not.

Direction within the crown influenced maximum $g_{\mathrm{s}}$ values. This seemed to depend on the compromise among optimal envi- 


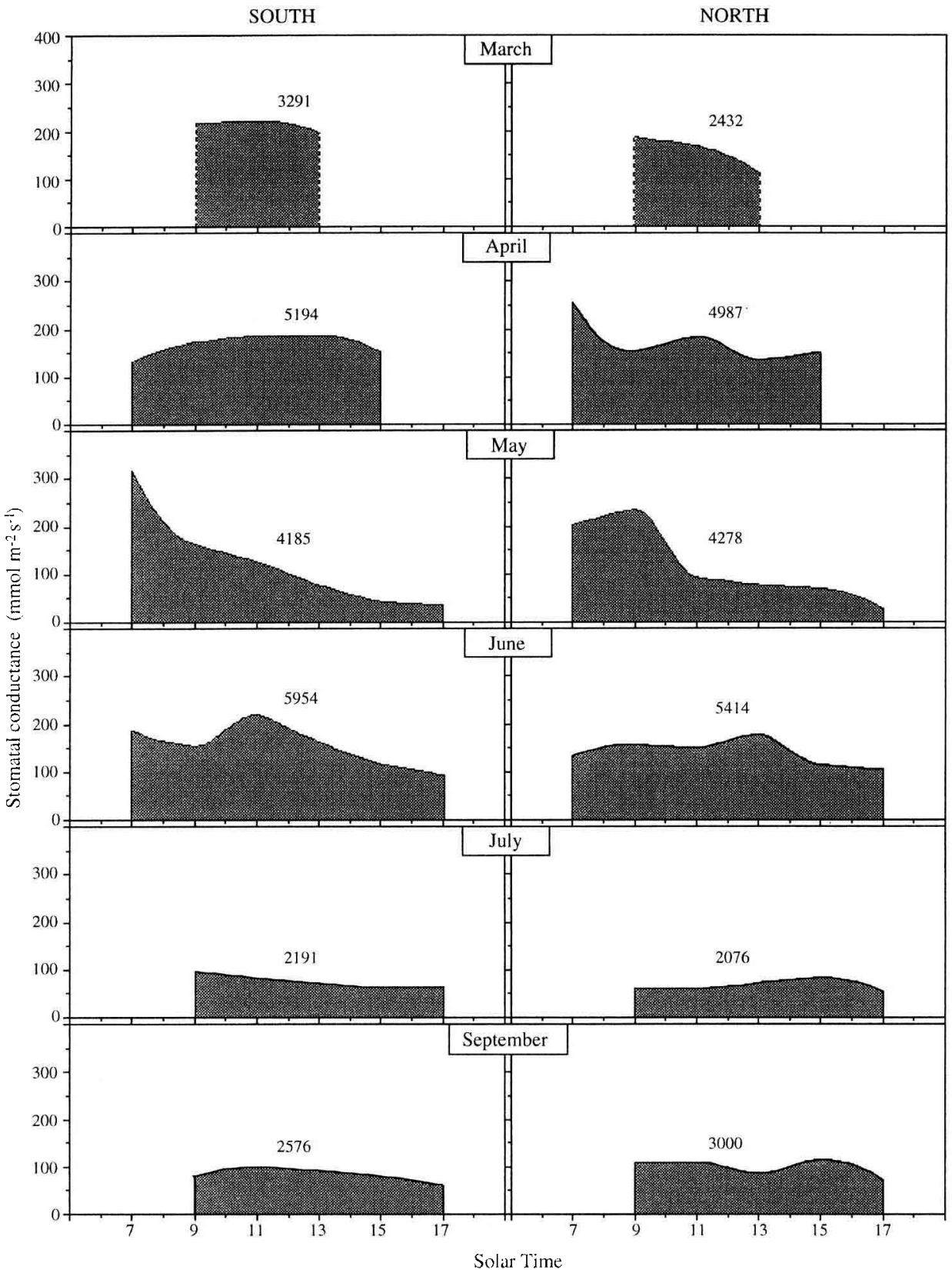

Fig 2. Average diurnal courses of stomatal conductance recorded from south- and north-exposed leaves of cork-oak throughut the year (pooled data from 1992 and 1993). Numbers indicate total daily stomatal conductance (mol. $\mathrm{m}^{-2} \cdot \mathrm{d}^{-1}$ ), and were estimated by integrating the daily curves of stomatal conductance on time. 
ronmental conditions (PPFD ${ }_{i}$, VPD and Tair) and on the time of day it occurred.

However, daily stomatal contribution was similar in all sections of the canopy, as a consequence of different leaf performances according to position in the crown. On the other hand, within-crown variability was not evident during periods of stronger environmental stress.

Although this is a case study performed on a single tree, it is a first approach to the sources of variation affecting leaf performance in isolated trees. These results, together with those previously reported on inter-tree variability (Oliveira et al, 1992, 1994), should be taken into account when planning field research in similar stands. Moreover, this work may provide some useful information for future modelling of oak productivity in these woodlands.

\section{ACKNOWLEDGMENTS}

We are grateful to the owners of $\mathrm{H}$ Pinheiro for permission to work on their property, and to all our colleagues who helped in the field work. This research was supported by JNICT grant BD/1630IE given to G Oliveira, and is part of the project MOST, financed by EU-Environment Programme EV 5V-CT92-0210.

\section{REFERENCES}

Acherar M, Rambal S, Lepart J (1991) Évolution du potentiel hydrique foliaire et de la conductance stomatique de quatre chênes méditerraneens lors d'une période de dessèchement. Ann Sci For 48, 561-576
Aubuchon RR, Thompson DR, Hinckley TM (1978) Environmental influences on photosynthesis within the crown of a white oak. Oecologia 35, 295-306

Dolman AJ, van den Burg GJ (1988) Stomatal behaviour in an oak canopy. Agric For Meteorol 43, 99-108

Hollinger DY (1989) Canopy organization and foliage photosynthetic capacity in a broad-leaved evergreen montane forest. Funct Eco/3, 53-62

Lo Gullo MA, Salleo S (1988) Different strategies of drought resistance in three Mediterranean sclerophyllous trees growing in the same environmental conditions. New Phytol 108, 267-276

Oliveira G, Correia OA, Martins-Loução MA, Catarino FM (1992) Water relations of cork-oak (Quercus suber $L$ ) under natural conditions. Vegetatio 99-100, 199-208

Oliveira G, Werner C, Mertens C, Correia O (1993) Influencia de la posición de la copa sobre la fenología y las relaciones hídricas del alcornoque (Quercus suber L). In: Proceedings Congreso Forestal Español-Lourizán 1993 (FJ Silva-Pando, G Vega Alonso, eds), vol 1, 277-282

Oliveira G, Correia O, Martins-Loução MA, Catarino FM (1994) Phenological and growth patterns of the Mediterranean oak Quercus suber L. Trees 9, 4146

Rhizopoulou S, Mitrakos K (1990) Water relations of evergreen sclerophylis. I. Seasonal changes in the water relations of eleven species from the same environment. Ann Bot 65, 171-178

Rhizopoulou S, Meletiou-Christou MS, Diamantoglou S (1991) Water relations for sun and shade leaves of four Mediterranean evergreen sclerophylls. J Exp Bot $42,627-635$

Sala A (1992) Water relations, canopy structure, and canopy gas exchange in a Quercus ilex forest: variation in time and space. Thesis, Universitat de Barcelona, Barcelona, Spain

Tenhunen JD, Lange OL, Gebel J, Beyschlag W, Weber JA (1984) Changes in photosynthetic capacity, carboxylation efficiency, and $\mathrm{CO}_{2}$ compensation point associated with midday stomatal closure and midday depression of net $\mathrm{CO}_{2}$ exchange of leaves of Quercus suber. Planta 162, 193-203 